\title{
Hydroponic: Empowering Local Farmer Knowhow to Gain Value Added on Agriculture Commodity
}

\author{
Andre Suryaningprang ${ }^{1}$, Jaja Suteja ${ }^{2}$, Mulyaningrum ${ }^{3}$, Erna Herlinawati ${ }^{4}$ \\ ${ }^{1,4}$ Sekolah Tinggi Ilmu Ekonomi Indonesia Membangun (Inaba), Indonesia \\ ${ }^{2,3}$ Universitas Pasundan, Indonesia \\ andre.suryaningprang@inaba.ac.id, jajasuteja@unpas.ac.id,mulyaningrum@unpas.ac.id, \\ ernaherlinawati@inaba.ac.id
}

\section{Abstract}

The agricultural sector is one of the potential commodities in business at domestic and abroad, local farmers in the West Java area are trying to run the best farming system that is adapted to market needs. Conventional farming systems that require large tracts of land, the availability of farmer labor and the length of time for harvesting are obstacles for local farmers to expand their businesses and increase their production yields. A concept in the agricultural system that is different from conventional agriculture yet can be used by local farmers at this time is hydroponic farming. Hydroponic farming that uses water as a planting medium can be implemented anywhere such as urban areas because it does not require large tracts of land. One of the hydroponic techniques that is currently developing is the NFT or Nutrient Film Technique which can be applied in the highlands and lowlands. This system can provide quality harvests. The NFT system provides added value for farmers by increasing farmers' knowledge about the hydroponic farming system and increasing agricultural commodities produced, through this system the farmers can run their farming business on land that is not extensive in urban areas. The commodities produced are of high quality because they are environmentally friendly, with efficient fertilizer, water and the use of non-pesticide ingredients. In fact, this hydroponic system requires a large enough cost to purchase material, regardless of the greater quantity of harvest and shorter harvest time. Increasing the quality and quantity of agricultural products encourage local farmers to run a hydroponic system in meeting market needs so that they have high economic value and can improve the welfare of local farmers.
Keywords

agriculture, hydroponics, Nutrient FilmTechnique(NF); local farmers

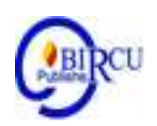

\section{Introduction}

Public awareness of healthy lifestyles that emerge at this time is encouraging farmers to prioritize the quality of their crops in meeting the needs of consumers. Due to limited land for agriculture, especially in densely populated urban areas, land that is infertile due to pollution becomes a barrier for farmers. While agricultural commodities in Indonesia are expected to meet the needs of domestic consumers and have a great opportunity to export abroad, farmers must have alternatives in their farming cultivation techniques.

Hydroponics is known as cultivation of plants that only use water and do not use soil as a planting medium. The hydroponic system can be used as a solution for modern crop cultivation and can be applied by farmers who have problems in the shortage of farmland 
because hydroponics can be empowered for narrow land. Hydroponics system that uses a growing medium in the form of water with proper nutrition and a controlled $\mathrm{pH}$ can be applied to plants whose fertilization process or germination takes place in a short time. Therefore, not all plants are ideal if they are planted with the concept of hydroponics. icu

Hydroponic techniques are mostly carried out on a small scale as a hobby among Indonesian people. But farmers can use this system by paying attention to what types of plants will be cultivated on a commercial business scale, because not all agricultural products are of economic value whether it is vegetables, fruits or ornamental plants.

Hydroponics also has several advantages including the cultivation that does not depend on climate, continuous crop yields, and more practical plant care, commodities that are often cultivated with hydroponics are horticultural commodities (Andrian et al, 2019). Some types of hydroponic plants that have high economic value in agricultural commodities such as green leafy vegetables are lettuce, spinach, kale, mustard greens, cucumbers and fruits such as tomatoes, melons, strawberries, grapes or other types such as cucumber, chilli and peppers.

Hydroponic processing is relatively easy because it does not require a lot of costs like other conventional planting techniques, there is energy efficiency of the farmers and if farmers run this system with intensive care, the plants will grow faster and provide sustainable production results so that the quantity and quality of crop production hydroponics can be guaranteed. This hydroponic cultivation process is environmentally friendly and safe to consume because it uses components that are free from contamination of harmful microorganisms and pesticides as well as the existence of control from farmers who are more intensive in controlling pests and diseases.

The current market needs for high-quality agricultural commodities, due to public awareness of the consumption of natural or organic vegetables, so that the selling value of hydroponic agricultural products also becomes high, increasing selling prices can help improve the welfare of farmers' lives and therefore this hydroponic system is quite lively implemented by local farmers.

\section{Review of Literatures}

\subsection{Hydroponic System}

Agricultural land is increasingly narrow due to the shifting of the function of agricultural land into industrial areas, so that hydroponic cultivation is considered appropriate to utilize available land because this cultivation system does not require soil media. The hydroponic system uses a variety of planting media other than soil, among others, with media such as fuel husk, husk, sand, zeolite, rockwoll, peat (peat moss) and coconut husk powder (Prihmantoro and Indriani in Zailani et al, 2019).

In 1842, a list of nine elements was believed to be essential for plant growth, and the discoveries of German botanists Julius von Sachs and Wilhelm Knop, in the years 1859-1865, triggered the development of landless cultivation techniques. [1] The growth of landless land plants with a solution that emphasizes meeting the nutritional needs of minerals for plants. It has quickly become the standard of research and learning techniques, and is still widely used today. Latter-day, Solution culture is considered as a type of hydroponics without inert planting media, which is a planting medium that does not provide nutrients.

Gericke (1929) began to openly promote the Solution culture used to produce agricultural crops. [2] [3] At first, he called it aquaculture (or in Indonesia it is called aquaculture), but later learned that aquaculture was applied to aquaculture. Gericke created a sensation by growing twenty-five-foot-spread tomatoes in his backyard with a solution of mineral nutrients other than soil. [4] 


\subsection{Hydroponic Advantages and Disadvantages}

\section{a. Hydroponic System Advantages}

1. No need land

2. Water will continue to circulate in the system and can be used for other purposes, for example made into an aquarium

3. Nutrition control is simpler so that nutrition can be provided more effectively and efficiently

4. Relatively does not produce nutrient pollution to the environment

5. Gives more yields and plants grow faster ( $2 \mathrm{x}$ fold)

6. Easy to harvest results

7. Sterile and clean

8. The growing media can be used repeatedly

9. Free from pests / weeds

\section{b. Hydroponic System Disadvantages}

1. Requires large capital

2. In substrate culture, the capacity of holding water of substrate media is smaller than the soil media so that it will cause rapid withering of plants and serious stress.

Various Types of Plants That Can Be Planted Hydroponically:

1. Types of hydroponic vegetables include Pokcoy, mustard greens, spinach, kale, kailan, lettuce, celery, etc.

2. Types of fruits include cucumbers, melons, chilies, tomatoes, eggplants and others.

3. Types of herbal plants such as mint, basil, coriander, and others.

4. Types of flower plants such as orchids and roses

\subsection{NFT System (Nutrient Film Technique)}

This NFT system is the most popular way in hydroponic terms. This NFT system continuously streams nutrients dissolved in water without using a timer for the pump. This nutrient flows into the gully through the roots of plants and then back again to the water reservoir, and so on.

NFT Advantages:

1. Plant growth is faster than other systems because the root needs of plants for water, nutrients and oxygen are fulfilled.

2. It's easy to control the nutritional state.

3. Very little risk of deposition of dirt in the gully.

4. Plant growth in all parts is even and uniform because the nutrients and water flow are the same.

NFT disadvantages:

1. The cost of making modules is quite large.

2. This system is very dependent on electricity.

3. Disease transmission is faster.) 


\section{Research Methods}

\subsection{Types and Research Methods}

This study uses a qualitative approach, according to Sugiyono (2012: 59) that in the qualitative research, researchers together with the help of others become the main data collection tools. In qualitative research the instrument or research tool is the research itself. Furthermore, Sugiyono (2012: 222) also states that qualitative researchers as human instruments, function to get the focus of research, choose information as a source of data, conduct data collection, assess data quality, analyze data, interpret data and make conclusions on its findings. Therefore, during the research process, researchers will communicate more with research subjects, namely one of the hydroponic garden farmers in the east Bandung area. Next will further describe descriptively in the findings.

Descriptive method is a research method that tries to describe and interpret objects as they are, from theoretical data and data from the field. This type of qualitative research as a research procedure that produces descriptive data in the form of written words from people and observed behavior (Meleong, 2004: 4)

\subsection{Data Collection Technique}

In qualitative research, data collection is done in natural settings (natural conditions) primary data sources, and data collection techniques are more on participant observation, indepth interviews and documentation (Sugiyono, 2016: 309). Sugiyono (2010: 63) states that: "In qualitative research, data collection is done in natural settings and data collection techniques are more on participatory observation, in-depth interviews, and documentation. Referring to this understanding, researchers interpret data collection techniques as a way to obtain data through several steps or stages, namely observation, interviews, documentation and trigulation. These steps serve to facilitate researchers in the process of obtaining data.

\section{a. Observation}

According to Nasution, observation is the basis of all knowledge. Scientists can only work based on data, namely facts about the world of reality obtained through observation ". (Sugiyono, 2016: 310). Observations used is participatory observation. In this participatory observation the researcher as a non-participant observer is directly involved with the daily activities of the hydroponic farmer only at the time of the study in order to see the farm process using the NFT Hydroponic technique.

\section{b. Interview}

Sugiyono (2014: 231) defines "an interview is a meeting of two people to exchange information and ideas through questions and answers, so that meaning can be constructed in a particular topic". This technique is a method of collecting data through one-sided questioning conducted systematically on the interviewee in accordance with the research objectives. In this case the researchers conducted interviews with hydroponic garden farmers to find out how to produce added value to agricultural commodities through the NFT Hydroponic technique.

\section{c. Documentation}

This technique is a record of events that have already passed. The document study is a complement to the use of observation and interview methods in qualitative research. Documents can be in the form of writing (diaries, biographies, regulations, policies, etc.), drawings, or monumental works of a person (Sugiyono, 2014: 240). The data in this study are also in the form of drawings of the hydroponic engineering process and the results of farm production that had been running before. 


\section{d. Triangulation}

Triangulation is defined as a data collection technique that combines various data collection techniques and data source already exists. When researchers conduct data collection techniques with triangulation, the researcher has collected data and at the same time tests the credibility of the data from various data sources.

Triangulation technique means researchers use different data collection techniques to get data from the same source, (Sugiyono, 2016: 330). Researchers use participatory observation, in-depth interviews, and documentation for the same data source simultaneously"

This research examines the data by testing the credibility of the data obtained by checking the data to the same source, namely the Hydroponic garden farmers with different data collection techniques. For example the data obtained by interviewing are then checked by observation or documentation regarding the production of farms produced.

\section{Results and Discussion}

\section{System Implementation}

In this research, hydroponic garden farmers use the NFT (NUTRIENT FILM TECHNIQUE) technique in their farming processes. This design is a fairly simple design in the application of the system and is very commonly used to grow plants that have a short harvest age such as green vegetables. Basically the NFT design can be modified by farmers but still refers to the same system pattern, which is from a very shallow nutrient solution flowing down through a pipe. Here, the roots of plants come into contact with water, and can absorb nutrients from it. So it must be ensured the flow of water must continue to run or not stop.

In running a hydroponic system with the NFT technique, several materials and systems must be made, namely:

Table 1. Material Equipment needed

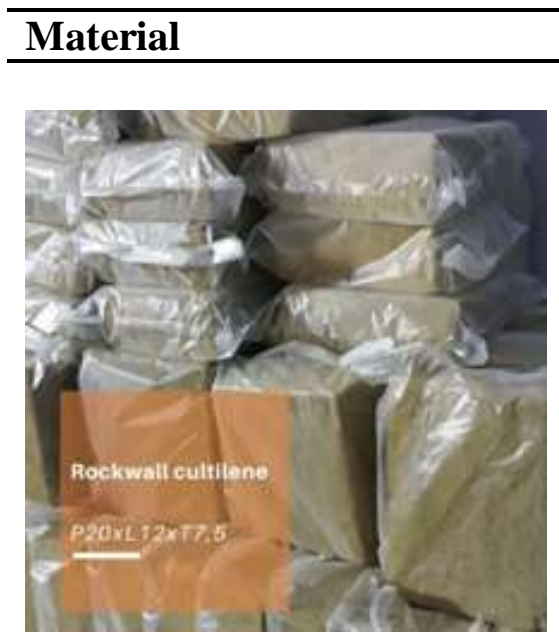
Information

Rockwool is a mineral fiber or mineral wool that is often used as a hydroponic growing media with fine fibers and has a light load where the planting media has advantages in terms of the ratio of water and air composition that can be stored. Rockwool is used for seeding. 

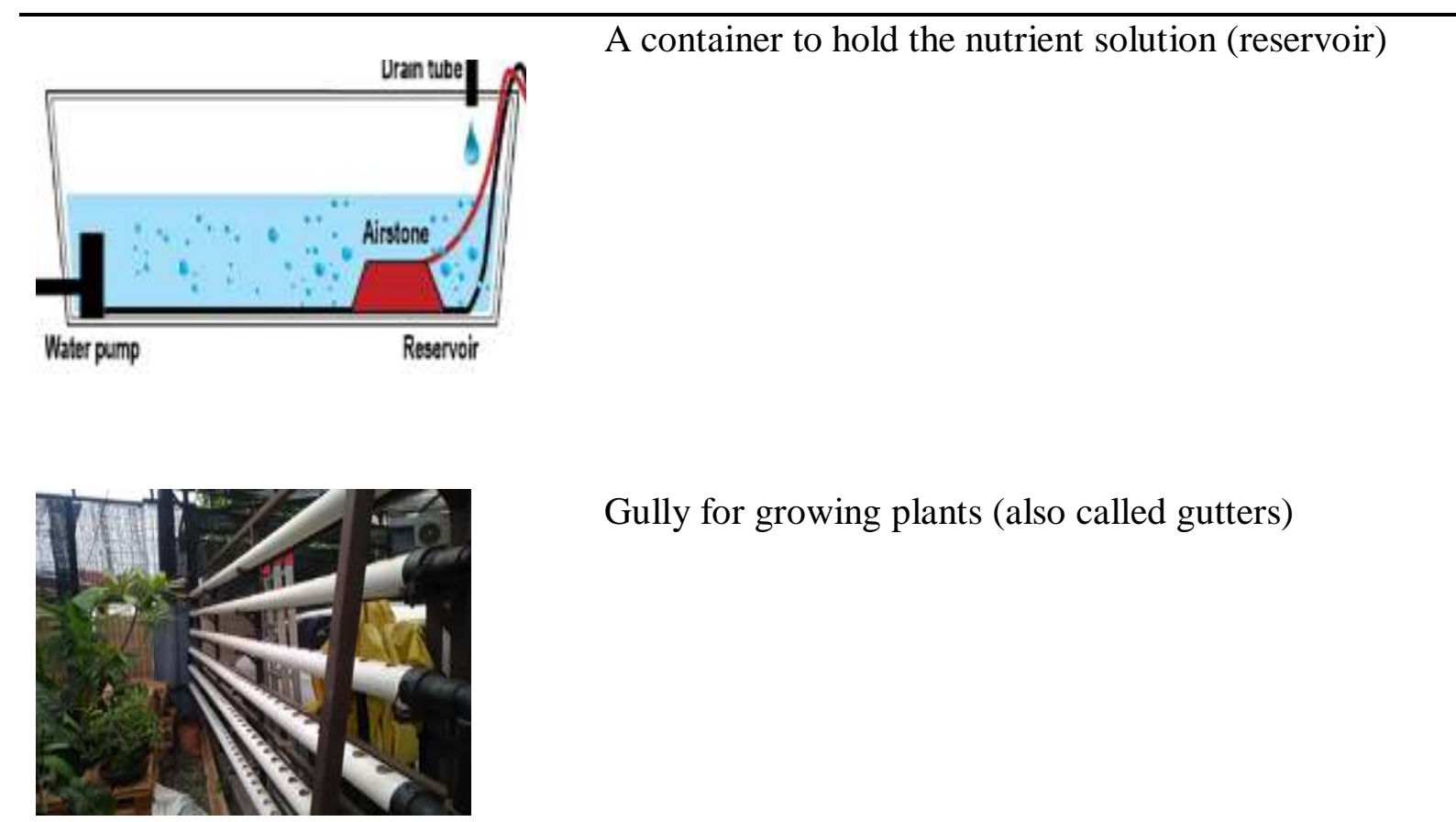

Gully for growing plants (also called gutters)

PH meter, as a measure of plant PH

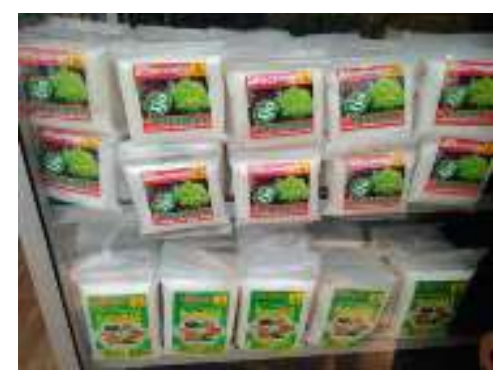

Nutrition Solution 


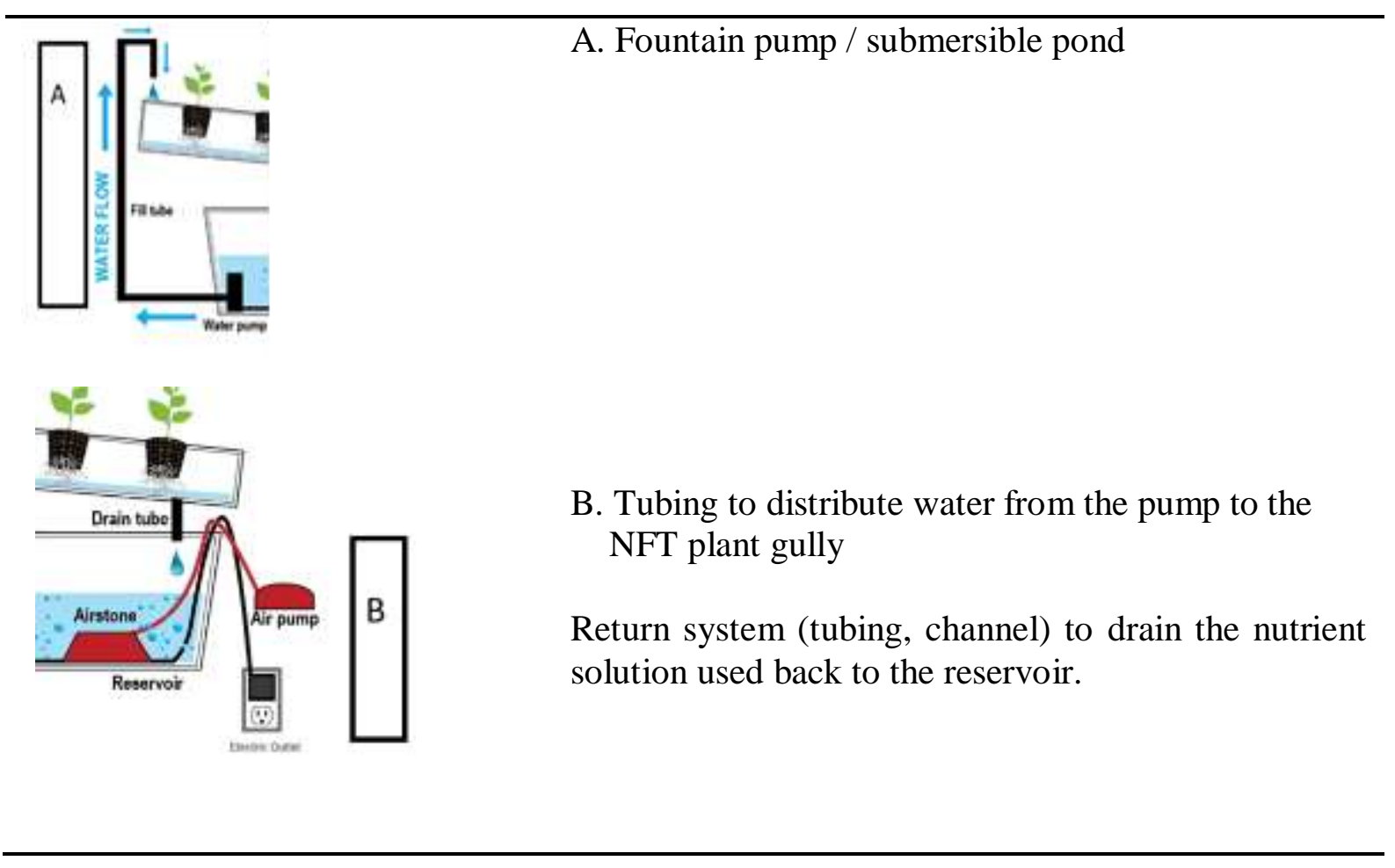

Table 2. NFT System Process

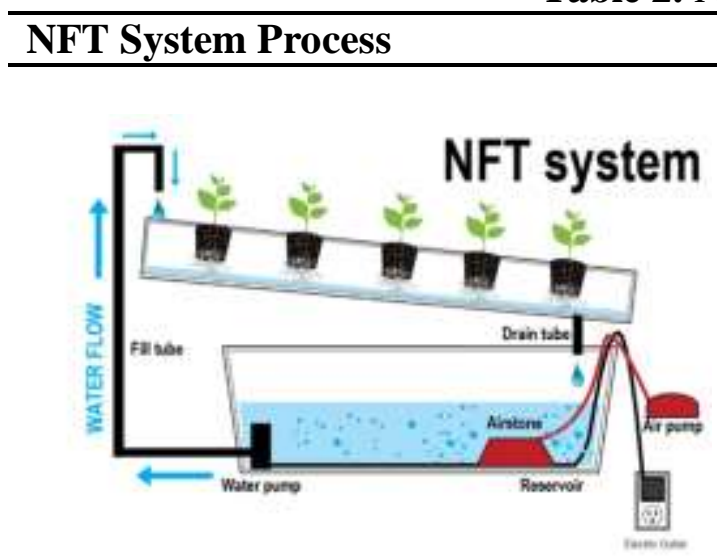
Information

Nutrient solutions are pumped from the reservoir, usually to the manifold that connects a larger tube to a smaller number. Each of these smaller tubes flows the nutrient solution to one side of each gully / grow channel / gutter with the plants inside.

A thin layer (film) of nutrient solution flows through each channel with plants in it to the other side, passing through each plant and soaking the roots at the bottom of the canal as it happens. Nutrient solutions flow from one side to the other because the channel is slightly tilted so that the water flows down the sloping surface. 


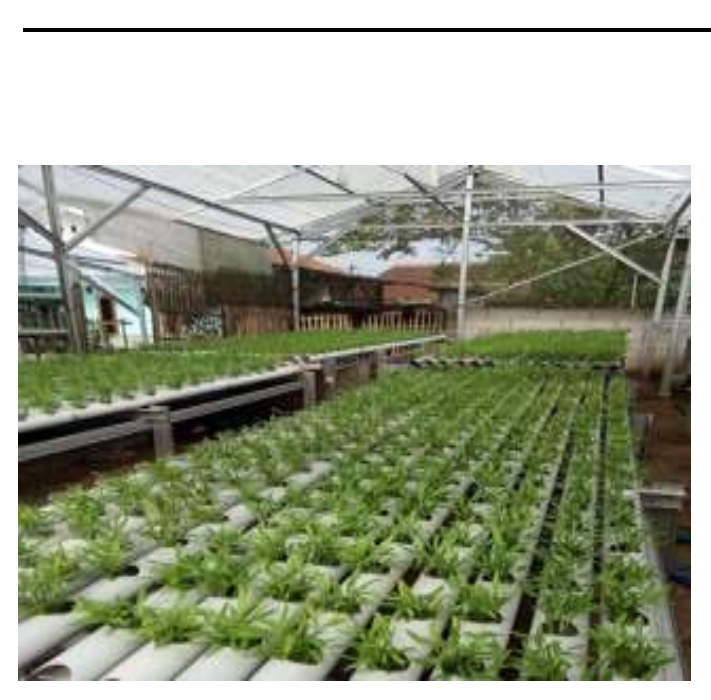

Plants in gully (channels/gutters) are usually placed on the water by placing seedlings starting in a rockwool cube or a small one-inch planting medium into a small hole at the top of the gully. Seedling roots are flooded at the bottom of the tube/canal where the roots get their nutrients from the shallow flow of the nutrient solution that flows. The excess nutrient solution flows out from the lower end of each channel to other channels or tubes, and is directed back to the reservoir where this solution is recirculated through the system.

Netpot and planting media that directly touch the bottom of the gully causes the roots to be directly exposed to the flow of nutrients.

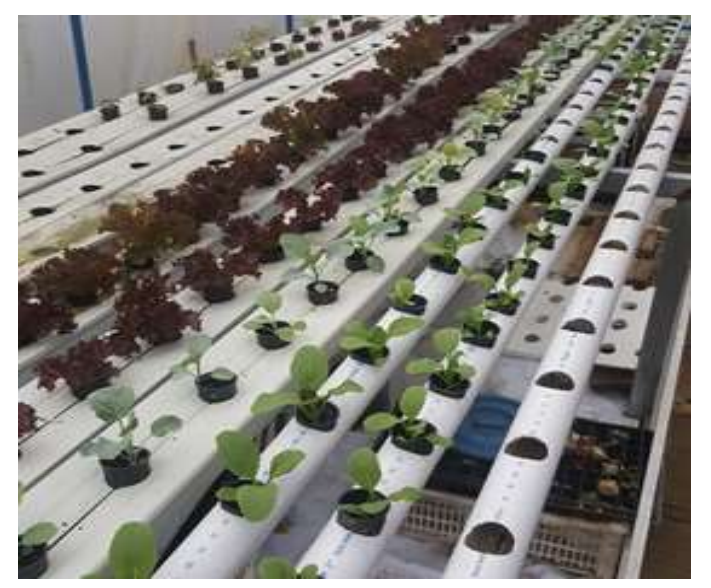

Stages in the NFT system:

- Manufacture of modules

- Seeding

- Transfers of seedlings from seddling tray to the module

- Transfer from module after seedling to maturity module

- Harvesting

- Cleaning / sterilizing the module if it has several times to avoid pests or pathogens that can be detrimental. 
Table 3. Results of Hydroponic Farmer Production using the NFT system

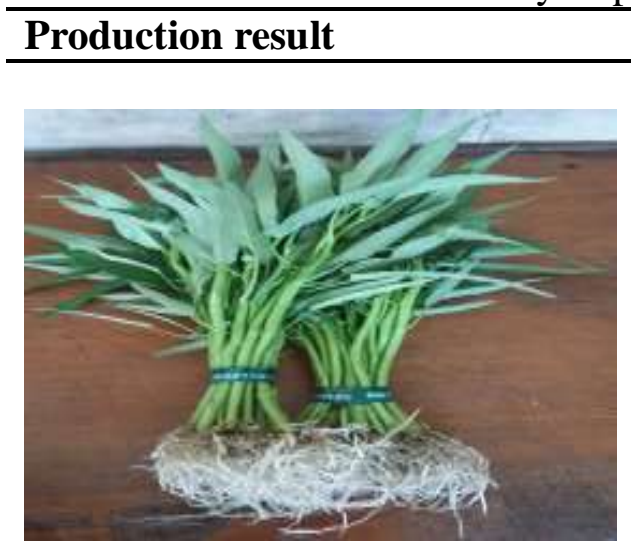

\section{Information}

Hydroponic plants tend to be more attractive and cleaner and the structure of plants is more attractive compared to conventional, tastes better and texture when consumed is more crispy because the plant nutrients are set by the farmers themselves, crop production is faster than conventional, but hydroponic plants tend to be more fragile with a high water content compared to conventional.

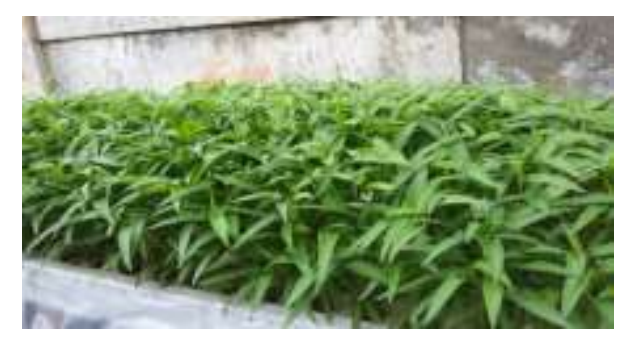

Plant growth tends to be better, because greater oxygen intake and water temperatures tend to be lower so that the absorption of nutrients is more maximal and the harvest age of plants is faster and more vigorous.

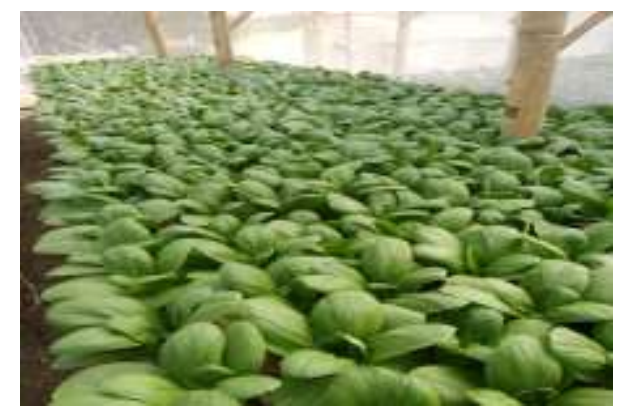

The agricultural commodities produced can be of various types except for perennials and large shapes, so these other commodities are very potential in terms of business in agricultural commodities because their products are more natural and faster in the process so that they can meet the needs of the community with high selling prices.

\section{Conclusion}

Based on the above research it can be concluded that the hydroponic farming system provides an opportunity for farmers to be able to increase the production of the farms they produce, the hydroponic farming system can produce yields in a faster time that is 15-21 days and more than using conventional systems. The quality of the crops produced is very good and natural because it does not use pesticides so it is more environmentally friendly, using nutrient solutions for fertilizer efficiency, water as a planting medium. The quality of the crop can meet the market demand for the public consumption of natural vegetables. Farmers can sell hydroponic agricultural products at a higher selling price compared to conventional ones so that the welfare index of farmers increases as indicated by data from BPS that there is an increase in Farmer Exchange Rates (NTP) nationwide which increased 0.58 percent in August 2019 by 103.22 compared the previous month which was 102.64 . The increase in FTT this time was due to the price index received by farmers rose 0.69 percent, higher than the increase in price index paid by farmers by 0.11 percent which was influenced by the increase in FTT in the four agricultural subsectors. With the use of the NFT Hydroponics system, farmers' 
knowledge and abilities have increased because farmers carried out routine control of the modules created so as to reduce the risk of crop failure and have a thorough understanding of the process of making hydroponic system modules until harvest time.

Suggestions for further research are an expanded research locus, longer research time, and exploring other techniques of a more efficient hydroponic farming system in terms of costs so that it can be an input for farmers who want to innovate in the farming system at a more economical cost but still able to produce quality crops.

\section{References}

Andrian, D., et al. (2019). The Use of Liquid Organic Fertilizer As Growth Media and Production of Kangkung (Ipomoea reptans Poir) Hydroponics. Budapest International Research in Exact Sciences (BirEx) Journal. P. 23-34.

a b Douglas, James S., Hydroponics, 5th ed. Bombay: Oxford UP, 1975. 1-3

Dunn, H. H. (October 1929). "Plant "Pills" Grow Bumper Crops". Popular Science Monthly: 29.

G. Thiyagarajan, R. Umadevi \& K. Ramesh, "Hydroponics," Science Tech Entrepreneur, (January 2007), Water Technology Centre, Tamil Nadu Agricultural University, Coimbatore, Tamil Nadu 641 003, India.

Bambi Turner, "How Hydroponics Works," HowStuffWorks.com. Retrieved: 29-05-2012

a b Liddell, H.G. \& Scott, R. (1940). A Greek-English Lexicon. revised and augmented throughout by Sir Henry Stuart Jones. with the assistance of. Roderick McKenzie. Oxford: Clarendon Press.

Anna Heiney, "Farming for the Future", nasa.gov, 8-27-04

Research News. "Commercial Aeroponics: The Grow Anywhere Story," In Vitro Report (Society for In Vitro Biology), Issue 42.2 (April - June 2008)

Stoner, R., "Aeroponics Versus Bed and Hydroponic Propagation", Florist Review, Vol 173 no.4477, September 22, 1983".

Stoner, R.J (1983). Rooting in Air. Greenhouse Grower Vol I No. 11

(Inggris) nasa.gov (2006). "Spinoff 2006" (PDF). diterbitkan oleh nasa.gov. hlm. 65-67, Detail info biomassa aeroponik. Diakses tanggal Agustus, 2015.

(Inggris) "Progressive Plant Growing is a Blooming Business". Diterbitkan oleh Nasa gov. 23 April 2007.

(Indonesia) Dianawati, M1), Ilyas, S2), Wattimena, GA2), dan Susila, AD2) (20 Februari 2013). "Produksi mini umbi kentang" (PDF). diterbitkan oleh LitBang pertanian: 47. Diakses tanggal Agustus, 2015.

Zailani, M., et al. (2019). Growth Response and Crop Production (Brassica Juncea L.) Against Watering Time Interval at Various Hydroponics Media. Budapest International Research in Exact Sciences (BirEx) Journal. P. 9-22. 